\title{
A case of food protein-induced enterocolitis syndrome to mushrooms challenging currently used diagnostic criteria
}

Séverine Serafini, Marcel Bergmann*, Philippe Eigenmann, Jean-Christoph Caubet

From Food Allergy and Anaphylaxis Meeting 2014

Dublin, Ireland. 9-11 October 2014

We present a case report of food protein-induced enterocolitis (FPIES) to mushrooms and highlight the caveats of diagnosing acute FPIES in clinical practice, particularly in older children and when solid foods are involved. The current clinical diagnostic criteria need to be revised based on the recent evidence to avoid underdiagnosis of FPIES.

Published: 30 March 2015

Submit your next manuscript to BioMed Central and take full advantage of:

- Convenient online submission

- Thorough peer review

- No space constraints or color figure charges

- Immediate publication on acceptance

- Inclusion in PubMed, CAS, Scopus and Google Scholar

- Research which is freely available for redistribution

Submit your manuscript at www.biomedcentral.com/submit 